\title{
S18 - Insuficiencia renal aguda en pacientes de la Unidad de Cuidados Intensivos, Hospital Regional de Cuilapa, Santa Rosa, Guatemala
}

\author{
Ronald J. Ajcalon \\ Escuela de Estudios de Posgrado, Facultad de Ciencias Médicas, Universidad de San Carlos de Guatemala.
}

*Autor al que se dirige la correspondencia: jhonnieal@yahoo.com

\section{Resumen}

T a insuficiencia renal aguda, es una condición común en la Unidad de Cuidados Intensivos de Adultos (UCIA) Ly probablemente una consecuencia de la enfermedad crítica que se asocia a resultados clínicos adversos, altos costos y una mortalidad de más del 50\%, sobre todo si se requiere tratamiento de reemplazo renal. El objetivo fue determinar la incidencia de insuficiencia renal aguda en pacientes ingresados a la UCIA. El estudio fue prospectivo, longitudinal, observacional, en 101 pacientes ingresados en la UCIA del Hospital Regional de Cuilapa. Se diagnosticaron 101 pacientes durante el periodo de estudio con insuficiencia renal aguda represento el $27.4 \%$ del total de pacientes internados (368) en el servicio en un año. La incidencia de mortalidad en pacientes que requieren terapia de reemplazo renal y se encuentran en ventilación mecánica es del 100\%. Del total de pacientes estudiados, según la escala Akin, se encontró que el 49.5\% de los pacientes correspondían a grado II, aunque el grado I también fue frecuente (29\%), y que el $22 \%$ de los pacientes correspondían a grado III. La patología que mayormente se asoció al desarrollo de insuficiencia renal aguda fue sepsis grave con un 31\%, seguido de pacientes sometidos a cirugía mayor e hipovolemia con el 21 y 18\% respectivamente. Se halló una incidencia aumentada de insuficiencia renal aguda comparado con estadísticas internacionales, cuya etiología fue mayormente causada por procesos sépticos.

Palabras claves: Escala Rifle, ecala Akin, terapia de reemplazo renal, hemodiálisis

\begin{abstract}
cute renal failure is a common condition in the Intensive Adult Care Unit (IACU) and probably a consequence Aof critical illness that is associated with adverse clinical outcomes, high costs and a mortality rate of more than $50 \%$, especially if it requires renal replacement therapy. The objective was to determine the incidence of acute renal failure in patients admitted to IACU. The study was prospective, longitudinal and observational in 101 patients admitted to the IACU at the Regional Hospital of Cuilapa study. A total of 101 patients were diagnosed during the study period with acute renal failure, which represent $27.4 \%$ of all patients in the IACU in one year (368). The incidence of mortality in patients requiring renal replacement therapy and with mechanical ventilation is $100 \%$. Of the patients studied, according to the AKIN scale, it was found that $49.5 \%$ of patients corresponded to grade II, although grade I was also common (29\%), and that $22 \%$ of patients corresponded to grade III. The pathology mostly associated with the development of acute renal failure was severe sepsis with $31 \%$, followed by patients undergoing major surgery and hypovolemia with 21 and 18\% respectively. It was found an increased incidence of acute renal failure compared to international statistics, whose etiology was mostly caused by septic processes.
\end{abstract}

Keywords: RIFLE scale, AKIN scale, renal replacement herapy, hemodialysis sobre protección a los derechos de autor, con criterio especificados en la licencia Creative Commons (CC BY-NC-SA 4.0) 